\title{
Infiltration and Sediment Production on a Deep Hardland Range Site in North Central
} Texas

\author{
J.H. BROCK, W.H. BLACKBURN, AND R.H. HAAS
}

\begin{abstract}
Greatest infiltration rate and lowest sediment production occurred in the honey mesquite canopy zone. Infiltration on shortgrass interspace areas was about one-half of the canopy zone rate. Terminal infiltration rates within the canopy zone and shortgrass interspace areas were affected little by brush control treatments. Infiltration rate improvement due to treatment occurred primarily in the midgrass interspace areas. Water-stable aggregates and the interaction of soil aggregate stability with the amount of bare ground were the dominant factors controlling infiltration. Sediment production on the shortgrass interspace was double that of the canopy zone or midgrass interspace areas. Low rate of sediment production on the midgrass interspace areas occurred on areas aerially sprayed or root plowed 3 years earlier. Sediment production was controlled primarily by an interaction of soil organic matter and amount of above-ground biomass or grass cover.
\end{abstract}

Past land management practices have resulted in large increases of honey mesquite (Prosopis glandulosa Torr. var. glandulosa) which now occurs on 56 million acres of Texas rangeland, including 34 million acres which are moderately to heavily infested (Fisher et al. 1973). Most of the heavily and moderately infested rangelands currently produce much less forage than their potential and require control of the honey mesquite to improve forage production.

Herbicides and root plowing are widely accepted tools for improving honey mesquite dominated rangelands. However, little information exists for Texas rangelands relative to the impact of honey mesquite control on infiltration rates and sediment production. In other areas, brush control practices have apparently increased infiltration rates and decreased erosion (Rosa and Tigerman 1951, Rich 1961, Rowe and Reimann 1961, Dragoun 1969, Blackburn and Skau 1974). Yet, in some cases, these practices have failed to improve watershed condition (Rowe and Reimann 1961, Blackburn and Skau 1974, Gifford and Busby 1974).

Blackburn (1975) reported sagebrush (Artemesia spp.) canopy zones to have exceedingly high infiltration rates, sometimes 3 to 4 times greater than the interspace areas. Likewise, sediment produced from interspace areas may range from none to as much as 46 times that of the corresponding canopy zones.

Our primary objective was to determine the influence of selected brush control practices on infiltration rates and sediment production from a mesquite-dominated hardland range site. A second objective was to identify the vegetation and soil parameters

The authors are presently assistant professor, Division of Agriculture, Arizona State University, Tempe, Arizona 85283; and associate professors, Range Science Department, Texas A\&M University, College Station, Texas 77843.

This report is published with approval of the Director, Texas Agr. Exp. Sta. as TA16109. The authors wish to acknowledge the cooperation of the W.T. Waggoner Estate in providing land and financial support for this study.

Manuscript received June 2, 1980. most closely associated with variations in infiltration capacity and sediment production.

\section{Study Area}

Field research was conducted on the W.T. Waggoner Estate southwest of Vernon, Texas. The estate is part of the Rolling Plains land resource area which comprises approximately 6.32 million ha of rolling to rough topography in northwest Texas (Gould 1975). Normal annual precipitation for Vernon, Texas, is about $65 \mathrm{~cm}$, with May, June, and October being the months of highest precipitation and January being the driest month (USDC 1976). The average frost-free period is 232 days (Koos et al. 1962).

Climax vegetation of the Rolling Plains include tall and midgrasses, but continuous heavy utilization by cattle has reduced the vegetation to primarily short and midgrasses with varying densities of woody plants. Honey mesquite, with a mean height of $1.6 \mathrm{~m}$, a mean density of 437 plants/ ha and a $21 \%$ canopy cover, dominated the study area prior to treatment. Lotebush (Ziziphus obtusifolia (T.G.) Gray), tasajillo (Opuntia leptocaulis D.C. var leptocaulis), and grassland prickly pear (Opuntia macrorhiza Engelm.) were common on the study area. Herbaceous vegetation was typified by Texas wintergrass (Stipa leucotricha Trin. and Rupr.), Arizona cottontop (Digitaria californica (Benth.) Henr.), little barley (Hordeum pusillum (Nutt.)), rescuegrass (Bromus unioloides (Willd.) H.B.K.), buffalograss (Buchloe dactyloides (Nutt.) Engelm.), sand dropseed (Sporobolus cryptandrus (Torr.) Gray), and purple threeawn (Aristida purpurea (Nutt.)).

Soil of the study area is Tillman clay loam, a member of the fine, mixed, thermic family of typic Paleustolls (Rogers et al. 1976) and one of the major soil series of the Deep Hardland range site.

Historically the study area was grazed yearlong, initially at a heavy rate, reducing to a moderate stocking rate of an animal unit/7.3 ha prior to study initiation. Grazing of cattle was permitted in the interval between treatment and measurement only during the winter months.

\section{Methods}

Infiltration rates, sediment production, and soil and vegetation characteristics were measured in August 1977 on areas treated with a selected brush control treatment: (1) no treatment; (2) an aerial spray in 1973 of 2,4,5-T ((2,4,5-trichlorophenoxy) acetic acid $)+$ picloram (4-amino-3,5,6-trichloropicolinic acid) (1:1) at $0.6 \mathrm{~kg} / \mathrm{ha}$ in a diesel oil-water emulsion (1:3) at 36.4 liters/ha total spray volume; and (3) an aerial spray of 2,4,5-T + picloram in 1974; or rootplowing in 1974. Rootplowing of the sod-forming vegetation was conducted without fins to minimize herbage damage and surface disturbance while providing control of the honey mesquite. Within each brush control treatment, three vegetation strata about the honey mesquite plants were studied: (1) shrub canopy zone; (2) 
shortgrass interspace; and (3) midgrass interspace. The area of mulch and soil accumulation within the plant drip line was defined as the "shrub canopy zone" and the "interspace zone" as the area between shrub canopies. The shrub canopy zone was often dominated by midgrass species following brush control. The canopy zone and midgrass interspace occurred as a matrix within a dominant shortgrass community. Six infiltration sampling plots were established within each vegetation strata on each brush control treatment.

\section{Infiltration}

A mobile drip-infiltrometer (Blackburn et al. 1974) was used to apply simulated rainfall to $0.5 \mathrm{~m}^{2}$ plots at a rate of $12.7 \mathrm{~cm}-\mathrm{hr}$ for $0.5 \mathrm{hr}$ on soil that was initially dry. The same water rate was applied on the plot $24 \mathrm{hr}$ later when the soil was at or near field capacity. Immediately after the first simulated rainfall event, the plots were covered with clear polyethylene plastic to reduce evaporation and maintain a uniform surface soil water content. Only the results from soils at field capacity are reported in this paper.

Infiltration rates were determined by subtracting the measured runoff from the measured precipitation at given time intervals. Runoff was collected at 5-minute intervals and measured by weight. The weight of runoff was converted to volume $(\mathrm{cm})^{3}$.

\section{Sediment Production}

Upon termination of the simulated rainfall, the runoff from each plot was thoroughly agitated and one-liter subsample was taken. The sediment of each subsample was filtered, dried at $105^{\circ} \mathrm{C}$ for 24 $\mathrm{hrs}$, weighed, converted to sediment production $(\mathrm{kg} / \mathrm{ha})$ which served as an index of potential sheet erosion. Sediment production data were converted to common logarithm for statistical analysis.

\section{Vegetation Cover and Standing Crop}

Percentage foliage cover of grasses and forbs, and soil surface covered by mulch and bare ground, were determined by ocular estimate on each plot from gridded sample quadrat. Grasses, forbs, and standing dead material were harvested to a $1.5-\mathrm{cm}$ stubble height, and mulch was collected from each plot after infiltration determination was completed. The material was oven-dried at $60^{\circ} \mathrm{C}$ and weighed to estimate above-ground biomass.

\section{Soils}

Antecedent soil moisture was determined by the gravimetric method and bulk density by the core method (Black 1965) for each runoff plot. Soil samples for these measurements were taken before each simulated rainfall event on areas adjacent to each runoff plot at depths of 0 to $3 \mathrm{~cm}$. Soil was collected from each plot to a depth of $10 \mathrm{~cm}$ after the final simulated rainfall event. Soil organic matter content was determined by chromic acid oxidation (Jackson 1958). Aggregate stability of the soils was estimated by assigning soil slaking percentages to soil aggregates placed in a series of wateralcohol solutions (Taylor and Ashcroft 1972).

Analysis of variance was used to evaluate all vegetation and soil parameters. Duncan's multiple range test $(P<0.5)$ as described by Steel and Torrie (1960) was used to separate means. Stepwise multiple regression analyses were used to determine the influence of soil and vegetation variables on infiltration rates and sediment production.

\section{Results and Discussion}

\section{Infiltration}

Regardless of treatment, terminal infiltration rates were significantly higher on the canopy zone than on the midgrass or shortgrass interspace areas (Fig. 1). Infiltration on the shortgrass vegetation zone was lowest, and only about $50 \%$ of the infiltration rate of the midgrass or canopy zones. Although botanical composition of the midgrass vegetation and the canopy zone vegetation were similar, small but significant difference in the infiltration rates was reflected by the greater standing crop, mulch cover, water stable aggregates, and lower soil bulk density of the canopy zone.

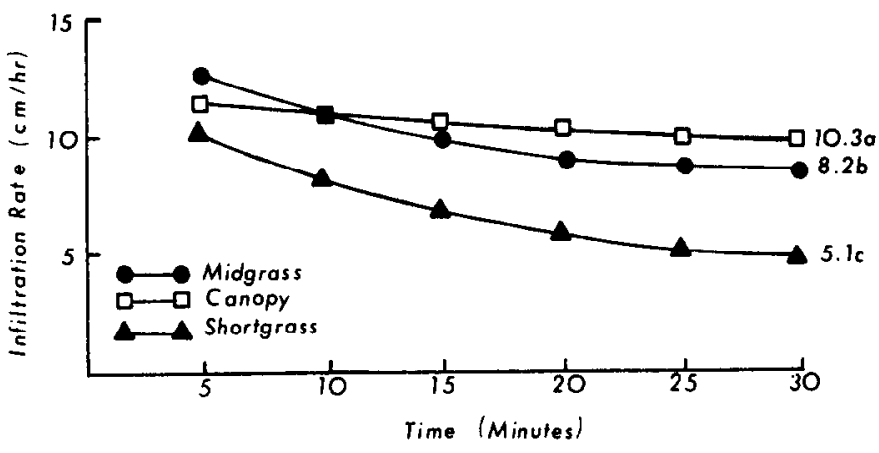

Fig. 1. Mean infiltration rates $(\mathrm{cm} / \mathrm{hr})$ on three vegetation zones associated with a Deep Hardland range site. Terminal infiltration rates followed by the same letter are not significantly different at $\mathrm{P}<.05$ level.

Terminal infiltration rates averaged across vegetation zones were significantly greater on the areas rootplowed and areas aerially sprayed in 1974 than on untreated areas (Fig. 2). The slight differences due to brush control treatments applied in 1974 were attributed to differences in soil bulk density on the areas treated in 1973 as compared to those treated in 1974 (Brock et al. 1978).

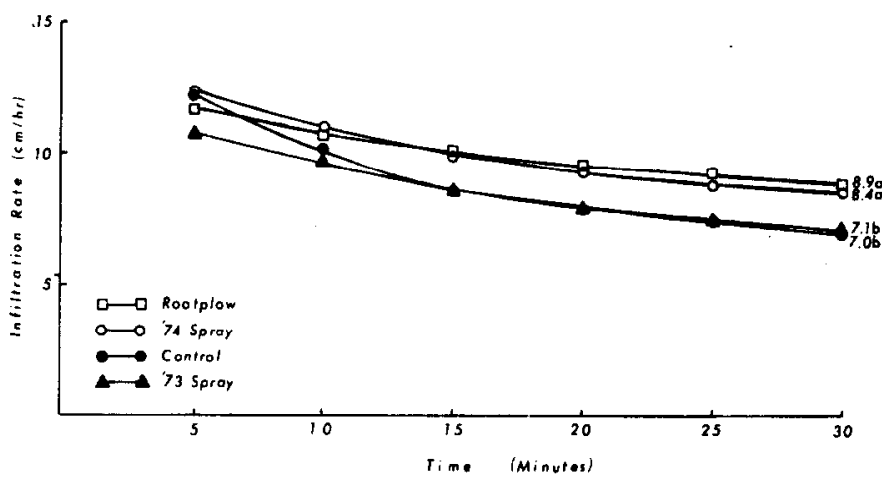

Fig. 2. Mean infiltration rates ( $\mathrm{cm} / \mathrm{hr}$ ) as influenced by brush control treatments. Terminal infiltration rates followed by the same letter are not significantly different at $\mathrm{P}<.05$ level.

Terminal infiltration rates within the canopy zone or the shortgrass interspace were only slightly affected by brush control practices (Table 1). There was a slight tendency for improved terminal infiltration rate following rootplowing within the shortgrass interspace. On the midgrass interspace areas, however, improvement of vegetation by the aerial spray treatments in 1974

Table 1. Terminal infiltration rates $(\mathrm{cm} / \mathrm{hr})$ for vegetation strata as influenced by brush control treatments, on a Deep Hardland range site at field capacity. 1

\begin{tabular}{llc}
\hline \hline Vegetation strata & Treatment & $\begin{array}{c}\text { Infiltration rate } \\
\text { (cm/hr) }\end{array}$ \\
\hline Canopy & Control & $10.3 \mathrm{a}$ \\
& 1973 Spray & $11.2 \mathrm{a}$ \\
& 1974 Spray & $9.6 \mathrm{ab}$ \\
Root Plow & $10.2 \mathrm{a}$ \\
Shortgrass & Control & $4.2 \mathrm{c}$ \\
& 1973 Spray & $4.1 \mathrm{c}$ \\
& 1974 Spray & $5.9 \mathrm{c}$ \\
& Root Plow & $6.3 \mathrm{bc}$ \\
Midgrass & Control & $6.6 \mathrm{~b}$ \\
& 1973 Spray & $6.2 \mathrm{bc}$ \\
& 1974 Spray & $9.7 \mathrm{ab}$ \\
& Root Plow & $10.1 \mathrm{a}$ \\
\hline
\end{tabular}

IVegetation strata treatment means followed by the same letter are not significantly different at $\mathbb{R}<.05$ level. 


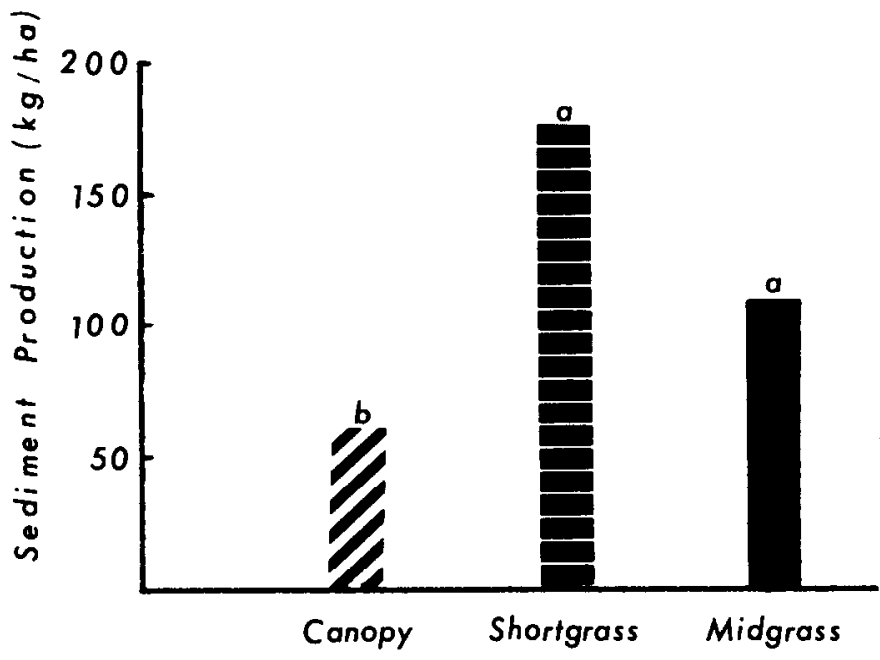

Fig. 3. Mean sediment production $(\mathrm{kg} / \mathrm{ha})$ on three vegetation strata associated with a Deep Hardland range site. Bars with the same letter are not significantly different at $\mathrm{P}<.05$ level.

and the disturbance caused by rootplowing increased infiltration rates. Wood and Blackburn (1980) studied the influence of livestock grazing on infiltration rates, and likewise, found that the midgrass interspace area was the only vegetation zone sensitive to grazing treatment. Multiple regression analyses indicate that the primary factors affecting infiltration rates in each of the vegetation strata were the stability of water-soluble soil aggregates, and the interaction of aggregate stability with the amount of bare ground. Simple regression analyses indicated that all cover factors were significantly related to the terminal infiltration rate. Although infiltration rate was inversely related to the amount of bare ground, it was directly related to grass cover, herbaceous standing crop, and aboveground biomass on the areas.

\section{Sediment Production}

Sediment production, measured from the runoff of each of the plots, was strongly affected by vegetation type. The canopy zone produced less than half the sediment of either the midgrass or the shortgrass interspaces (Fig. 3). Also, greater sediment production was recorded on untreated areas than on areas treated with the brush control methods (Fig. 4). Although it was hypothesized that sediment production would be accelerated by rootplowing, rootplowing and spraying significantly reduced the amount of sediments produced at approximately 30 months following the latest treatment.

There was a significant interaction of brush control treatment

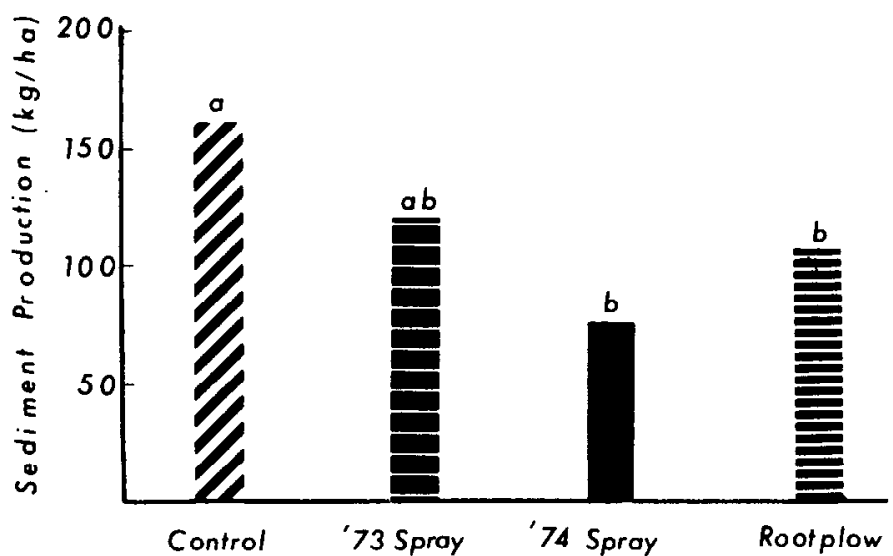

Fig. 4. Mean sediment production ( $\mathrm{kg} / \mathrm{ha}$ ) as influenced by brush control treatments. Bars with the same letter are not significantly different at $\mathrm{P}<$.05 level. with vegetation zone on sediment production. Within the area aerially sprayed in 1973, there was less sediment produced in the canopy zone, as compared to either the shortgrass or midgrass interspaces (Table 2). The reduction in sediment production in the canopy zone as a result of this treatment was due to the large amount of accumulated biomass under the dead mesquite trees. Less sediment was produced in the canopy zone after aerial spraying in 1973 than on the other areas. Low rates of sediment production also occurred on the midgrass interspace areas aerially sprayed or root plowed in 1974.

Table 2. Mean sediment production ( $\mathrm{kg} / \mathrm{ha}$ ) as influenced by vegetation strata and brush control treatments on a Deep Hardland range site. ${ }^{1}$

\begin{tabular}{lccc}
\hline \hline & & \multicolumn{2}{c}{ Interspace } \\
\cline { 3 - 4 } Treatment & Canopy & Shortgrass & Midgrass \\
\hline Control & $59 \mathrm{de}$ & $252 \mathrm{a}$ & $169 \mathrm{ab}$ \\
1973 Spray & $19 \mathrm{e}$ & $189 \mathrm{a}$ & $143 \mathrm{ab}$ \\
1974 Spray & $79 \mathrm{~cd}$ & $100 \mathrm{bc}$ & $32 \mathrm{de}$ \\
Rootplow & $80 \mathrm{~cd}$ & $138 \mathrm{abc}$ & $95 \mathrm{bcd}$ \\
\hline
\end{tabular}

'Means followed by the same letter are not significantly different at $\mathcal{R} .05$ level.

The amount of bare ground, standing crop, grass cover, and above-ground biomass were the primary factors influencing sediment production in the canopy zones. In the shortgrass and midgrass areas, sediment production was significantly related to bare ground, bulk density, grass cover, soil organic matter, and standing crop.

Multiple regression analyses for sediment production indicate various interacting factors reduced sediment production. In the canopy zone the interactions of soil organic matter content and above-ground biomass plus the interaction of soil organic matter and bare ground accounted for $57 \%$ of the variation in sediment production (Table 3). Variations in bulk density and the same interactions accounted for $49 \%$ of the variation in sediment production on the shortgrass areas. In the midgrass areas, the only significant factor contributing to sediment production was aboveground biomass, which accounted for $37 \%$ of the variation in sediment production.

The data from this study indicate that different factors are associated with variations in infiltration rate and sediment production. Soil aggregate stability and the interaction of this parameter with the amount of bare ground apparently regulate infiltration rates. Therefore, on the Deep Hardland range site, infiltration rates will reflect inherent variations in soil aggregate stability and the impact of range improvement practices on increasing plant cover.

Sediment production is strongly influenced by the interaction of soil organic matter content and the amount of aboveground biomass or soil cover. On soils of high bulk density, as is the case in the shortgrass interspace areas, any improvement in the amount of cover appears to greatly reduce sediment production. Therefore, allowing the vegetation cover to increase through deferrment of grazing would seem to be a logical practice for reducing soil erosion and for increasing the amount of soil water.

Table 3. Multiple regresion equations for sediment production (kg/ha) from three vegetation strata within a Deep Hardland range site.'

\begin{tabular}{|c|c|c|}
\hline $\begin{array}{l}\text { Vegetation } \\
\text { strata }\end{array}$ & Regression equation & $R^{2}$ \\
\hline Canopy & $\mathrm{Y}=3.6978-.0009\left(\mathrm{X}_{\mathrm{OM}} \mathrm{X}_{\mathrm{Bio}}\right)+.0202\left(\mathrm{X}_{\mathrm{BG}} \mathrm{X}_{\mathrm{OM}}\right)$ & .57 \\
\hline Shortgrass & $\begin{aligned} \mathrm{Y}= & 2.0814-.0009\left(\mathrm{X}_{\mathrm{OM}} \mathrm{X}_{\mathrm{Bio})}+2.2988\left(\mathrm{X}_{\mathrm{BK}}\right)\right. \\
& +.0133\left(\mathrm{X}_{\mathrm{BG}} \mathrm{X}_{\mathrm{OM}}\right)\end{aligned}$ & .49 \\
\hline Midgrass & $\mathrm{Y}=5.8871-.0017\left(\mathrm{X}_{\mathrm{OM}} \mathrm{X}_{\mathrm{BIO}}\right)$ & .37 \\
\hline
\end{tabular}

' Habitat variables were included in the model by a default probability program with a minimum of $P=10$. Variable names are: $Y=$ sediment production; $O M=$ organic matter (\%): $B$ io $=$ above ground biomass $(\mathrm{kg} / \mathrm{ha}$ ); $\mathbf{B G}=$ ba reground $(\%) ; \mathrm{BK}=$ bulk density. 


\section{Literature Cited}

Black, C.A. (ed.). 1965. Methods of soil analysis. Amer. Soc. Agron. Series No. $9.1572 \mathrm{p}$.

Blackburn, W.H. 1975. Factors influencing infiltration and sediment production of semiarid rangelands in Nevada. Water Resourc. Res. 11:929-937.

Blackburn, W.H., and C.M. Skau. 1974. Infiltration rates and sediment production of selected plant communities in Nevada. J. Range Manage. 27:476-480.

Blackburn, W.H., R.o. Meeuwig, and C.M. Skau. 1974. A mobile infiltrometer for use on rangeland. J. Range Manage. 27:322-323.

Brock, J.H., R.H. Haas, and J.C. Shaver. 1978. Zonation of herbaceous vegetation associated with honey mesquite in northcentral Texas. In: D.N. Hyder (ed.). Proc. First Internat. Rangeland Congress, Soc. Range Manage. p. 187-189.

Dragoun, F.J. 1969. Effect of cultivation and grass on surface runoff. Water Resourc. Res. 5:1078-1083.

Fisher, C.E., G.O. Hoffman, and C.J. Scifres. 1973. The mesquite problem, p. 5-9. In: Mesquite: Growth and development, management, economics, control and uses. Texas Agr. Exp. Sta., Res. Monogr. 1.

Gifford, G.F., and F.E. Busby. 1974. Intensive infiltrometer studies on a plowed big sagebrush site. J. Hydrology 21:81-90.

Gould, F.W. 1975. Texas plants: A checklist and ecological summary. Texas Agr. Exp. Sta. MP-585/Revised. 121 p.
Jackson, M.L. 1958. Soil Chemical Analysis. Prentice Hall, Inc., Englewood Cliffs, N.J. 498 p.

Koos, W.M., J.C. Williams, and M.L. Dixon. 1962. Soil survey for Wilbarger County Texas. U.S. Dep. Agr. Soil Conserv. Serv. and Texas Agr. Exp. Sta. 64 p.

Rich, L.R. 1961. Surface runoff and erosion in the Lower Chaparral zone, Arizona. U.S. Dep. Agr. Forest Serv., Rocky Mountain Forest Range Exp. Sta., Res. Pap. No. 66.

Rogers, C.A., G.D. Passmore, and W.M. Risinger. 1976. Soil survey for Baylor County, Texas. U.S. Dep. Agr. Soil Conserv. Serv. and Texas Agr. Exp. Sta. 67 p.

Rosa, J.M., and M.H. Tigerman. 1951. Some methods for relating sediment production to watershed condition. U.S. Dep. Agr. Forest Serv., Intermountain Forest Range Exp. Sta., Res. Pap. No. 26.

Rowe, P.B., and L.F. Reimann. 1961. Water use by brush, grass and grassforb vegetation. J. Forest. 59:175-181.

Steel, G.D., and J.H. Torrie. 1960. Principles and Proced ures of Statistics. McGraw-Hill Book Co., Inc., New York. 481 p.

Taylor, S.A., and G.L. Ashcroft. 1972. Physical Edaphology. W.H. Freeman and Co., San Francisco. 533 p.

U.S. Department of Commerce. 1976. National Oceanic and Atmospheric Administration, Climatological Data, Texas. Vol. 78.

Wood, M.K., and W.H. Blackburn. 1980. Grazing systems: Their influence on infiltration rates in the rolling plains of Texas. J. Range Manage. 34:331-335.

\section{Application Invited for Posi- tion of \\ Executive Secretary of Society for Range Management}

The Executive Secretary shall serve as the Chief Administrative Officer of the Society for Range Management; is accountable to the Board of Directors and is under the immediate supervision of the President.

DATE JOB TO BE FILLED:

August 1, 1982 or as soon thereafter as selected candidate is available.

\section{SALARY:}

Commensurate with experience and qualifications.

\section{QUALIFICATIONS:}

Demonstrated ability in public relations and communication, both internal and external to the SRM.

Demonstrated ability in organization management and administration.

Desire and ability to serve SRM members and Sections on an international basis.

Education and/or experience in range management or the renewable resource sciences that are basic to range management.

Effectiveness in working with volunteer organizations.

\section{SPECIFIC DUTIES:}

The Executive Secretary shall supervise the Society's office and its employees and be responsible for (1) all files and financial records of the Society, the expenditure of funds, the receipt and deposit of money, the management of investments and the audit of records; (2) the keeping of records of membership (5500 or more members), dues payments. Section affiliation, mailing lists, dues notices and correlation of records with those of the Sections; (3) service to Board of Directors, Society committees and to Sections; (4) issuing ballots for election of officers; (5) serving as managing editor of the Journal of Range Management and Rangelands and special publications; (6) seeking and originating opportunities to represent the Society and to project its image; (7) assisting the educational and informational programs and projects of the Society; (8) responding to inquiries and personal contacts regarding the Society and attending selected meetings; (9) assisting and participating actively in membership recruitment; and (10) coordinating activities associated with Society meetings.

\section{EQUAL OPPORTUNITY EMPLOYER:}

Applicants will be considered without discrimination for reasons such as age, race, religion, sex or national origin.

\section{APPLICATIONS:}

Applications will be evaluated beginning June 15, 1982. Applications will be receivable until the position is filled. Candidates should send a resume, three or more references and a letter of application to the chairman of the Search Committee:

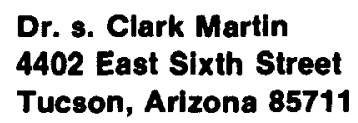

